\title{
Factors Influencing Iron utilization of Iron Compound/Carbon Nanofiber Composite Electrode
}

\section{Minato EGASHIRA*}

\author{
College of Bioresource Sciences, Nihon University, 1866 Kameino, Fujisawa, Kanagawa 255-0880, Japan
}

* Corresponding author: egashira.minato@nihon-u.ac.jp

\begin{abstract}
A comparative study of composite electrodes consisting of nanoparticles of iron compounds with fibrous nanocarbon in alkaline electrolyte was conducted to ascertain the morphological or composition factors that can increase the iron capacity. The preparation method and the iron content of a composite electrode affect the capacity per unit of iron mass. Particularly by increasing the iron content using a solution process, the capacity can be increased considerably up to ca. $\left.460 \mathrm{mAh}^{\mathrm{g} \mathrm{Fe}}\right)^{-1}$ for an $\mathrm{Fe}(\mathrm{OH})_{x} /$ carbon composite. Such improved iron utilization in these composites suggests a catalytic effect of some intermediate species. Addition of a model candidate of an intermediate species, $\mathrm{FeOOH}$, even of only $3 \mathrm{wt} \%$, can improve the iron utilization in a $\mathrm{Fe}(\mathrm{OH})_{x} / \mathrm{carbon}$ composite.
\end{abstract}

(c) The Electrochemical Society of Japan, All rights reserved.

Keywords : Alkaline Secondary Batteries, Iron Negative Electrode, Carbon Nanofiber

\section{Introduction}

Iron has been an attractive negative electrode material for use in alkaline secondary batteries because of its resource abundance, high theoretical capacity based on $\mathrm{Fe}^{0} / \mathrm{Fe}^{2+}$ redox (ca. $960 \mathrm{mAh} \mathrm{g}^{-1}$ ), and solid-state charge-discharge processes without dendrites. Secondary batteries including iron negative electrode have been investigated as well-known Edison batteries and trials on iron-air secondary batteries during the 1970 s for electric vehicle applications. ${ }^{1-3}$ With respect to iron negative electrodes for these batteries, the depth-ofcharge of iron in practical cells has been as low as approximately one-tenth of its theoretical value. A main reason for the low depthof-charge of iron electrodes, here meaning the percentage of working iron within the total mass, is the passivation by the oxidation product of iron. ${ }^{1,4-10}$ Several attempts have been made to prepare composites of iron and conductive materials to prevent iron species from passivation. ${ }^{11-14}$ Recently, Kao et al. demonstrated the improved capacity based on iron of ca. 600 and ca. $1000 \mathrm{mAh} \mathrm{g}^{-1}$ with rather good cycle stability by compositing iron with carbon black or copper. Hang et al. also succeeded in achieving ca. $600 \mathrm{mAh} \mathrm{g}^{-1}$ at several cycles by compositing with various carbons, particularly carbon nanofibers. ${ }^{15-18}$ Indeed, these recent developments have been sudden and somewhat remarkable in the history of iron negative electrodes. The author has made some contribution by compositing iron species with fibrous carbons, which presents advantages such as a large surface area that allows good contact with iron, and sufficient conductivity along the fiber axis..$^{19,20}$ This study was undertaken with the aim of 'linking' the research history by varying the compositing conditions of iron species with a fibrous nano-carbon substrate. Here preparation methods of two kinds have been applied: sol-gel precipitation and ultrasonic mixing of nano$\mathrm{Fe}_{3} \mathrm{O}_{4}$. Throughout comparative studies with varying iron/carbon composition, peculiar dependence on the iron content has been found. The reason for the behavior has been discussed in relation to the iron discharge reaction process.

\section{Experimental}

\subsection{Preparation of composite electrodes}

The nano-carbon substrate used in this study, hereinafter denoted as $\mathrm{CNF}$, is vapor-grown carbon fiber $\left(\mathrm{VGCF}^{\mathrm{TM}}-\mathrm{X}\right.$; Showa Denko
K.K., Japan) with ca. $20 \mathrm{~nm}$ fiber diameter. CNF was irradiated ultrasonically for $30 \mathrm{~min}$ in ethanol before use. Composite electrodes of iron and CNF were prepared via two procedures: sol-gel precipitation and ultrasonic-assisted mixing. The sol-gel precipitation of iron hydroxide in alkaline solution has been reported previously. ${ }^{20}$ In a typical case, $1 \mathrm{~mol} \mathrm{dm}^{-3} \mathrm{KOH}$ aq. was titrated into $100 \mathrm{~cm}^{3}$ suspension of $1 \mathrm{~mol} \mathrm{dm}^{-3} \mathrm{HCl}$ containing $0.2 \mathrm{~g}$ of CNF and the prescribed amount of $\mathrm{FeCl}_{3} \cdot 6 \mathrm{H}_{2} \mathrm{O}$ until the $\mathrm{pH}$ of the suspension became greater than 9 . The precipitation was then filtrated and dried under vacuum. Therefore, the products by this process are denoted hereinafter as $\mathrm{Fe}(\mathrm{OH})_{x}(\mathrm{w}) / \mathrm{CNF}$. In some cases, the initial suspension contains $20 \mathrm{wt} \%$ of poly(ethylene glycol) (PEG; Kanto Chemical Co. Inc., Japan, average molecular weight 300) so that the concentration of $\mathrm{HCl}$ was maintained to $1 \mathrm{~mol} \mathrm{dm}^{-3}$. The products in these cases are denoted hereinafter as $\mathrm{Fe}(\mathrm{OH})_{x}(\mathrm{p}) / \mathrm{CNF}$. For these sol-gel precipitation processes, the $\mathrm{Fe} / \mathrm{C}$ gravimetric ratio in the sources $\mathrm{FeCl}_{3} \cdot 6 \mathrm{H}_{2} \mathrm{O}$ and $\mathrm{CNF}$ were controlled to $1 / 9,2 / 8,3 / 7$, $4 / 6,5 / 5,6 / 4$, and $7 / 3$. For the mechanical mixing of nano-sized $\mathrm{Fe}_{3} \mathrm{O}_{4}(20-30 \mathrm{~nm}$ average particle size; Iolitec Inc., USA) with CNF under ultrasonic irradiation, nano- $\mathrm{Fe}_{3} \mathrm{O}_{4}$ and $\mathrm{CNF}$ were dispersed into ethanol and were irradiated ultrasonically for $30 \mathrm{~min}$ in an ultrasonic bath. The filtrated and dried product is denoted hereinafter as $\mathrm{Fe}_{3} \mathrm{O}_{4} / \mathrm{CNF}$.

\subsection{Measurements}

The iron contents of the prepared composites were found using a UV-VIS spectrometer (UV-mini 1240; Shimadzu Corp., Japan) based on the standard method in ISO6332 for buffer solution preparation. The iron content was detected from $510 \mathrm{~nm}$ absorption. The gravimetric contents of iron in the composites obtained from these analyses are denoted for specifications. The morphologies of the composites were observed using TEM (TEM1010; JEOL, Japan) and SEM (S-3500N; Hitachi Ltd., Japan).

These composite electrodes were mixed with $5 \mathrm{wt} \%$ of poly(tetrafluoroethylene) (PTFE, Daikin, Japan) binder, molded into a sheet. In some cases, commercial FeOOH (Kanto Chemical Co. Inc., Japan) of ca. $3 \mathrm{wt} \%$ was added to the preparation of the $\mathrm{Fe}(\mathrm{OH})_{x} / \mathrm{CNF} / \mathrm{PTFE}$ electrode sheet. A 7-mm-diameter disk was cut from the sheet, pressed onto platinum mesh (100 mesh; The Nilaco Corp., Japan), and used as the working electrode. The active mass in one disk was approximately $5-10 \mathrm{mg}$. A three-electrode test 

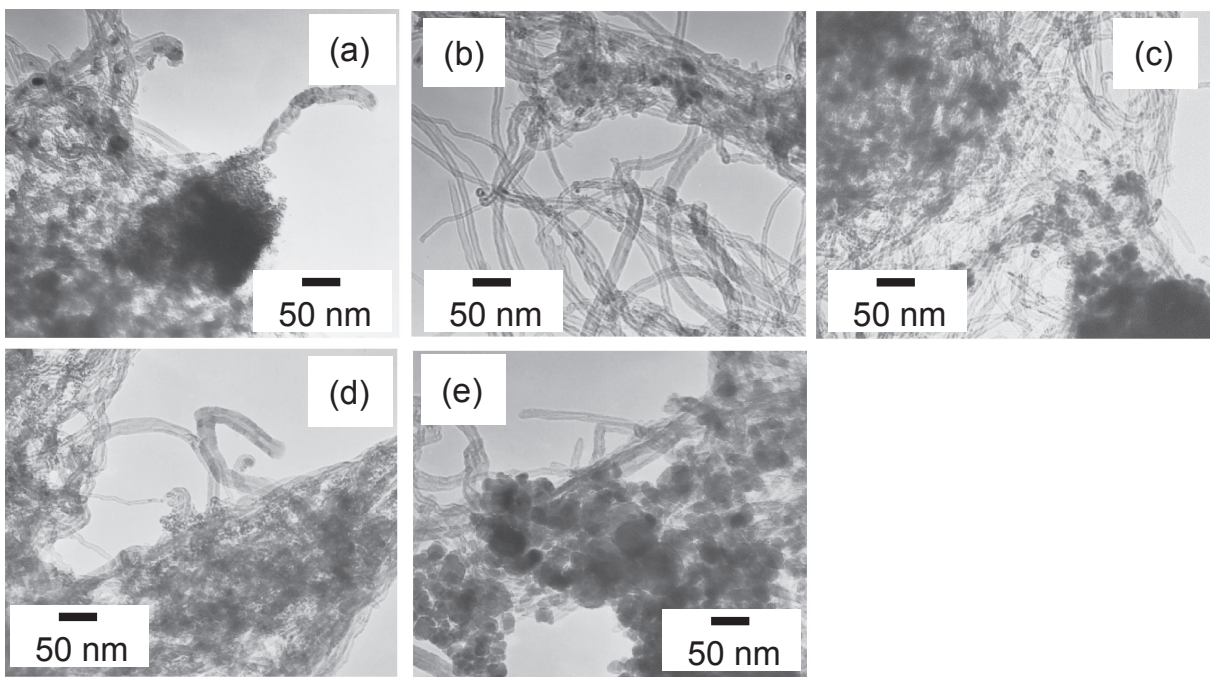

Figure 1. TEM images of various iron/carbon nanofiber composites. (a) $\mathrm{Fe}(\mathrm{OH})_{x}(\mathrm{w}) / \mathrm{CNF}(\mathrm{Fe}$ content 0.25$),(\mathrm{b}) \mathrm{Fe}(\mathrm{OH})_{x}(\mathrm{p}) / \mathrm{CNF}(\mathrm{Fe}$ content 0.22), (c) $\mathrm{Fe}_{3} \mathrm{O}_{4} / \mathrm{CNF}$ (Fe content 0.27), (d) $\mathrm{Fe}(\mathrm{OH})_{x}(\mathrm{p}) / \mathrm{CNF}$ (Fe content 0.30), (e) $\mathrm{Fe}_{3} \mathrm{O}_{4} / \mathrm{CNF}$ (Fe content 0.42).

cell for plate-type test electrode (BAS Inc., Japan) was used for electrochemical measurements. The working electrode, a counter electrode (platinum wire, attached with the cell) and $\mathrm{Hg} / \mathrm{HgO}$ as the reference electrode (RE-6A; BAS) were assembled in the test cell. The electrolyte was a binary alkaline solution $1 \mathrm{~mol} \mathrm{dm}^{-3} \mathrm{LiOH}$ and $2 \mathrm{~mol} \mathrm{dm}^{-3} \mathrm{KOH}$, to accelerate the reduction of iron oxide..$^{21,22}$ The electrode performance was evaluated via a combination of constant-potential charging (reduction) and constant-current discharge (oxidation). At the constant-potential charging, the potential of composite electrode was fixed at $-1.15 \mathrm{~V}$ vs. $\mathrm{Hg} / \mathrm{HgO}$ during $1 \mathrm{~h}$. The constant-current discharging process was started immediately after the charging process and was conducted under the current rate of $50 \mathrm{~mA}$ per unit of active mass. The cut-off potential was $-0.35 \mathrm{~V}$ vs. $\mathrm{Hg} / \mathrm{HgO}$. The measurements were conducted using a computer-controlled automatic polarizer (1286; Solartron Analytical). The cell temperature during measurements was controlled to $298 \mathrm{~K}$ by a temperature chamber (SU-221; Espec Corp., Japan). The charge-discharge tests or some cases were conducted by application of constant-current on charging. The cycle performances of thesecomposite electrode have not been discussed, mainly because the drying-out of electrolyte in the open-air test cell with a small volume for the electrolyte inhibits long-term experimentation for more than ten cycles.

\section{Results and Discussion}

Figure 1 portrays TEM images of $\mathrm{Fe}(\mathrm{OH})_{x}(\mathrm{w}) / \mathrm{CNF}$ (Fe content $0.24), \mathrm{Fe}(\mathrm{OH})_{x}(\mathrm{p}) / \mathrm{CNF}$ (Fe content $0.22,0.30$ ), and $\mathrm{Fe}_{3} \mathrm{O}_{4} / \mathrm{CNF}$ (Fe content $0.27,0.42$ ). All these images show particles of several tens-of-nanometers with aggregation, attributed to iron oxide or hydroxide, loaded on tubes with $20-30 \mathrm{~nm}$ diameter, attributed to CNF. The $\mathrm{Fe}(\mathrm{OH})_{x}(\mathrm{p}) / \mathrm{CNF}$ appears to be a less aggregated, and thereby rather dispersed feature compared with $\mathrm{Fe}(\mathrm{OH})_{x}(\mathrm{w}) / \mathrm{CNF}$. Although the catalog particle sizes of $\mathrm{Fe}_{3} \mathrm{O}_{4}$ are $20-30 \mathrm{~nm}$, the observed $\mathrm{Fe}_{3} \mathrm{O}_{4}$ particles are also aggregated to several hundred nanometers. Some $\mathrm{Fe}_{3} \mathrm{O}_{4}$ aggregates are dispersed into $20-30 \mathrm{~nm}$ of primary particles and loaded on CNFs. $\mathrm{Fe}(\mathrm{OH})_{x}$ particles are amorphous and are difficult to characterize structurally, whereas ferrous hydroxide has been reported to be a mixture of such species as $\mathrm{Fe}_{2} \mathrm{O}_{3}, \mathrm{Fe}_{3} \mathrm{O}_{4}$, and $\mathrm{FeOOH} .{ }^{4}$ The $\mathrm{Fe}(\mathrm{OH})_{x}(\mathrm{p}) / \mathrm{CNF}$ and $\mathrm{Fe}_{3} \mathrm{O}_{4} /$ $\mathrm{CNF}$ with high iron loading display TEM images of similar sized particles of iron species and CNF with a larger number of particles. These particles of iron species still lie along CNF and therefore appear to have a mutual connection.
The discharge (oxidation) profiles of various iron/CNF composites with various iron contents obtained after the constant-current charging are displayed in Fig. 2. In these profiles, the "(specific) capacities" are the capacities per unit weight of the composite electrodes. CNF itself clearly exhibits negligible capacity. However, all the iron/CNF composites show plateaus around $-0.9 \mathrm{~V}$ and $-0.8 \mathrm{~V}$. The capacities on this plateau are varied with the iron content and the compositing method. The author has assessed the capacities of the $\mathrm{Fe}(\mathrm{OH})_{x}(\mathrm{p}) / \mathrm{CNF}(0.30 \mathrm{Fe})$ and the $\mathrm{Fe}_{3} \mathrm{O}_{4} / \mathrm{CNF}(0.55 \mathrm{Fe})$ by constant-current charging, which revealed that these electrodes show similar capacities to those under constant-potential charging, as shown in Fig. 2(d). The charge-discharge efficiencies for these electrodes are ca. $70-75 \%$ because of the hydrogen evolution byreaction on charging process. The utilization of iron in these chargedischarge tests is regarded as determined by the conversion rate to a metallic state in the charging process, whereas the rigorous utilization on this process is hindered because of the hydrogen evolution. To clarify the dependence on these factors, the capacities from these profiles are shown toward the iron content in Fig. 3(a). Indeed, the capacity for a plateau at $-0.9 \mathrm{~V}$ is not reproducible whereas the sum for these plateaus at $-0.9 \mathrm{~V}$ and $-0.8 \mathrm{~V}$ is reproducible. Consequently, the capacities are defined here as the sum of the plateaus of $-0.9 \mathrm{~V}$ and $-0.8 \mathrm{~V}$. The capacity increases by the increase of the iron content up to 0.30 for $\mathrm{Fe}(\mathrm{OH})_{x} / \mathrm{CNF}$ and 0.65 for $\mathrm{Fe}_{3} \mathrm{O}_{4} / \mathrm{CNF}$. Assuming excess iron content, the iron species with less contact with conductive $\mathrm{CNF}$ might increase. The $\mathrm{Fe}_{3} \mathrm{O}_{4}$ / $\mathrm{CNF}$, consisting of conductive $\mathrm{Fe}_{3} \mathrm{O}_{4}$, retains rather high capacity under high loading of iron compared with $\mathrm{Fe}(\mathrm{OH})_{x} / \mathrm{CNF}$. Among the $\mathrm{Fe}(\mathrm{OH})_{x} / \mathrm{CNF}$ composites prepared via the solution route, $\mathrm{Fe}(\mathrm{OH})_{x}(\mathrm{p}) / \mathrm{CNF}$ prepared using the $\mathrm{PEG}$-added bath provides higher capacity than $\mathrm{Fe}(\mathrm{OH})_{x}(\mathrm{w}) / \mathrm{CNF}$ with similar iron content because of the dispersion of smaller particles of less-conductive $\mathrm{Fe}(\mathrm{OH})_{x}$ on CNF. The effect of the addition of a colloid modifier at the precipitation bath of the solution route has been displayed here.

The utilization of iron in a composite electrode is displayed more clearly by the specific capacity per actual mass of iron. The capacities based on the iron mass are shown in Fig. 3(b). The highest iron-based capacities for the $\mathrm{Fe}(\mathrm{OH})_{x}(\mathrm{w}) / \mathrm{CNF}$ composites, ca. $330 \mathrm{mAh}\left(\mathrm{g} \mathrm{Fe}^{-1}\right.$, are smaller than those of the other composites, probably because of the larger particle/aggregate size of $\mathrm{Fe}(\mathrm{OH})_{x}$. The unit $\mathrm{mAh}\left(\mathrm{g} \mathrm{Fe}^{-1}\right.$ represents the capacity $\mathrm{mAh}$ per gram of iron for a composite. The addition of PEG300 in the precipitation bath is so effective that the specific capacity based on the iron mass improves to ca. $460 \mathrm{mAh}\left(\mathrm{g} \mathrm{Fe}^{-1}\right.$ under Fe content of 0.36 . The 
Electrochemistry, 83(11), 984-988 (2015)
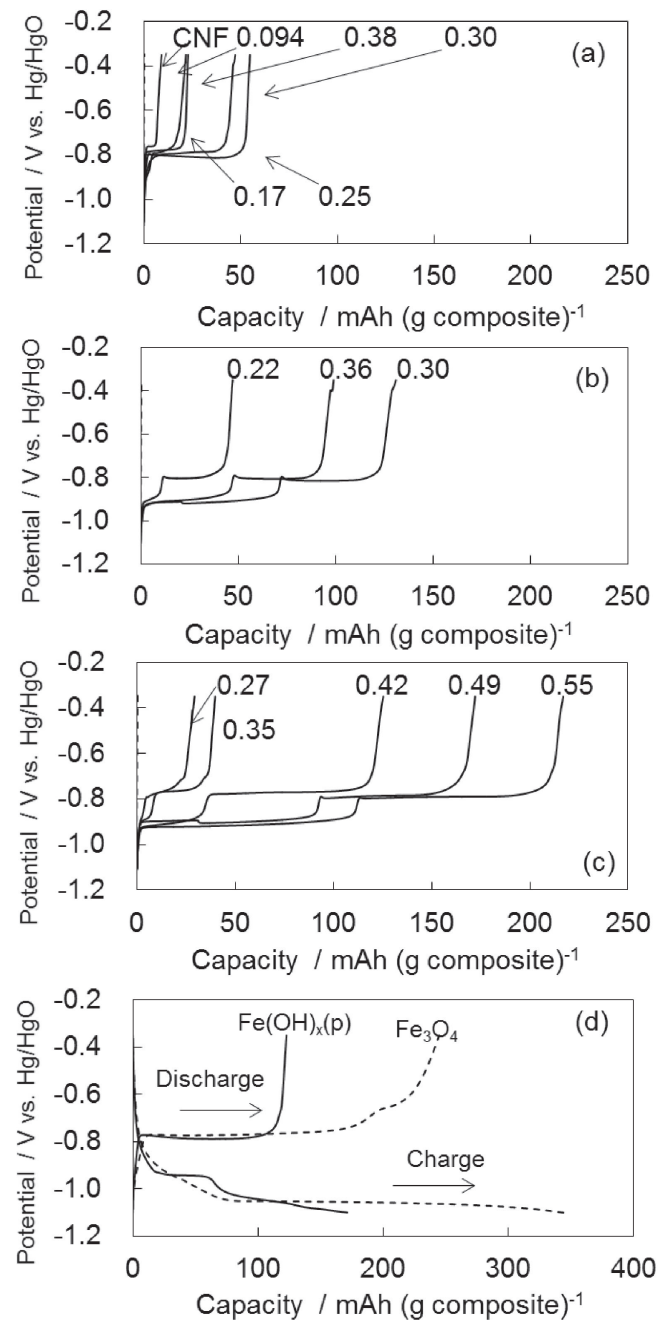

Figure 2. Discharge profiles of various iron/carbon nanofiber composite electrodes. (at cycle with highest capacity; Fe contents shown in the figure) Electrode: (a) $\mathrm{Fe}(\mathrm{OH})_{x}(\mathrm{w}) / \mathrm{CNF}$, (b) $\mathrm{Fe}(\mathrm{OH})_{x}(\mathrm{p}) / \mathrm{CNF}$, (c) $\mathrm{Fe}_{3} \mathrm{O}_{4} / \mathrm{CNF}$, (d) Charge-discharge profile of $\mathrm{Fe}(\mathrm{OH})_{x}(\mathrm{p}) / \mathrm{CNF}\left(\mathrm{Fe} 0.36\right.$ ) and $\mathrm{Fe}_{3} \mathrm{O}_{4} / \mathrm{CNF}$ ( $\mathrm{Fe} 0.55$ ), Current density: $50 \mathrm{~mA}$ (g composite) ${ }^{-1}$, Cut-off potential: $-0.35 \mathrm{~V}$ vs. $\mathrm{Hg} /$ $\mathrm{HgO},-1.10 \mathrm{~V}$ vs. $\mathrm{Hg} / \mathrm{HgO}$ (at (d)).

capacity per iron for the $\mathrm{Fe}_{3} \mathrm{O}_{4} / \mathrm{CNF}$ composites are lower than $\mathrm{Fe}(\mathrm{OH})_{x}(\mathrm{p}) / \mathrm{CNF}$ containing $0.36 \mathrm{Fe}$, although the higher loading of $\mathrm{Fe}_{3} \mathrm{O}_{4}$ up to 0.55 provides high capacity per iron, ca. $430 \mathrm{mAh}$ $(\mathrm{g} \mathrm{Fe})^{-1}$. Sol-gel precipitation might be beneficial for the dispersion of small particles of iron species, but the higher bulk conductivity of $\mathrm{Fe}_{3} \mathrm{O}_{4}$ than that of $\mathrm{Fe}(\mathrm{OH})_{x}$ might allow high loading.

Irrespective of the compositing method, the utilization of iron is low for low iron content. It increases with the increase of iron content to the maximum. Particularly, both $\mathrm{Fe}(\mathrm{OH})_{x}(\mathrm{p}) / \mathrm{CNF}$ and $\mathrm{Fe}_{3} \mathrm{O}_{4} / \mathrm{CNF}$ show marked increases of capacity per unit of iron content for iron contents of 0.30 for $\mathrm{Fe}(\mathrm{OH})_{x}(\mathrm{p}) / \mathrm{CNF}$ and 0.50 for $\mathrm{Fe}_{3} \mathrm{O}_{4} / \mathrm{CNF}$. One might imagine that lower iron content is beneficial for the utilization of iron by improving the electron conduction iron species via CNF. The opposite trends shown in the present cases suggest some additional phenomenon that compensates for the shortcomings in the connection to CNF during the charge-discharge of the composite electrodes with high iron loading. The increase of the iron content leads not to the increase of the particle size, but to the increase of numbers of nanoparticles along CNFs, as shown in Fig. 1. Composites with high iron utilization have numerous connections among such nanoparticles. An acceptable explanation for the increase of the capacity of iron by the increase of iron content

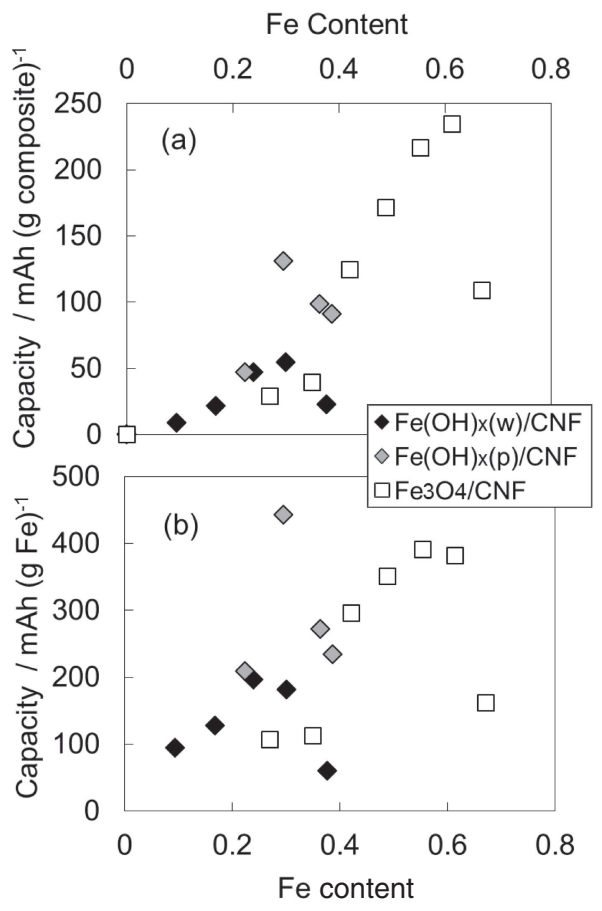

Figure 3. (a) Capacity plot versus iron content in iron/carbon nanofiber composites. (b) Dependence of capacities per mass of iron on iron content in iron/carbon nanofiber composites.
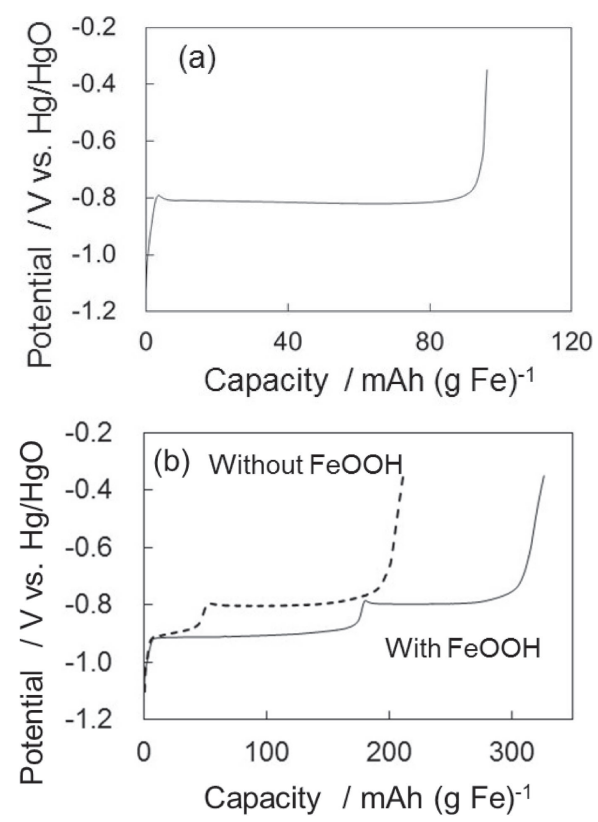

Figure 4. (a) Discharge profiles of $\mathrm{FeOOH}$ in alkaline electrolyte. (b) Discharge profiles of $\mathrm{Fe}(\mathrm{OH})_{x}(\mathrm{p}) / \mathrm{CNF}$ (Fe content 0.22 ) with and without $3 \mathrm{wt} \%$ of $\mathrm{FeOOH}$. Current density, $50 \mathrm{~mA}(\mathrm{~g} \mathrm{Fe})^{-1}$; cutoff potential, $-0.35 \mathrm{~V}$ vs. $\mathrm{Hg} / \mathrm{HgO}$.

is the acceleration of iron reduction by some intermediate species. Here iron oxyhyoxide $\mathrm{FeOOH}$ is regarded as an example intermediate. This material can be acquired as a reagent. Thereby the addition effect of this material for a composite electrode has been attempted. The charge profile of $\mathrm{FeOOH}$ after mechanical mixing with $\mathrm{CNF}$ in an agate mortar for 0.42 of iron, and discharged via a similar method to the composite electrodes is shown in Fig. 4(a). The discharge capacity increases along with the cycle and achieves ca. $230 \mathrm{mAh}\left(\mathrm{g} \mathrm{Fe}^{-1}\right.$ at the third cycle. The capacity is rather 

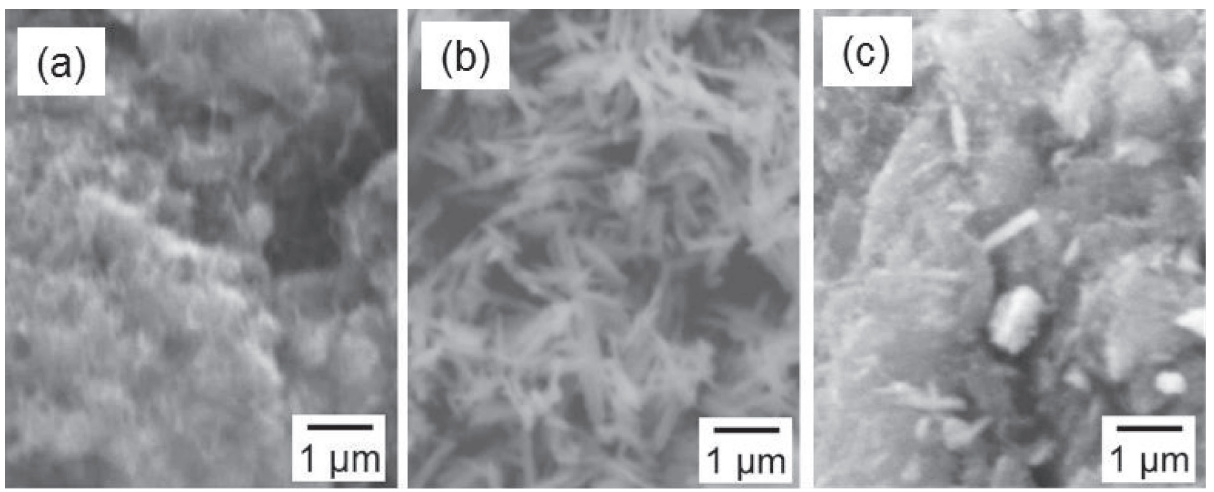

Figure 5. SEM images of $\mathrm{Fe}(\mathrm{OH})_{x}(\mathrm{p}) / \mathrm{CNF}, \mathrm{FeOOH}$ and related materials. (a) $\mathrm{Fe}(\mathrm{OH})_{x}(\mathrm{p}) / \mathrm{CNF}$ ( $\mathrm{Fe}$ content 0.22$)$ without $\mathrm{FeOOH}$, (b) SEM image of $\mathrm{FeOOH}$ powder, (c) SEM image of $\mathrm{Fe}(\mathrm{OH})_{x}(\mathrm{p}) / \mathrm{CNF}$ (Fe content 0.22 ) with 3 wt\% $\mathrm{FeOOH}$.
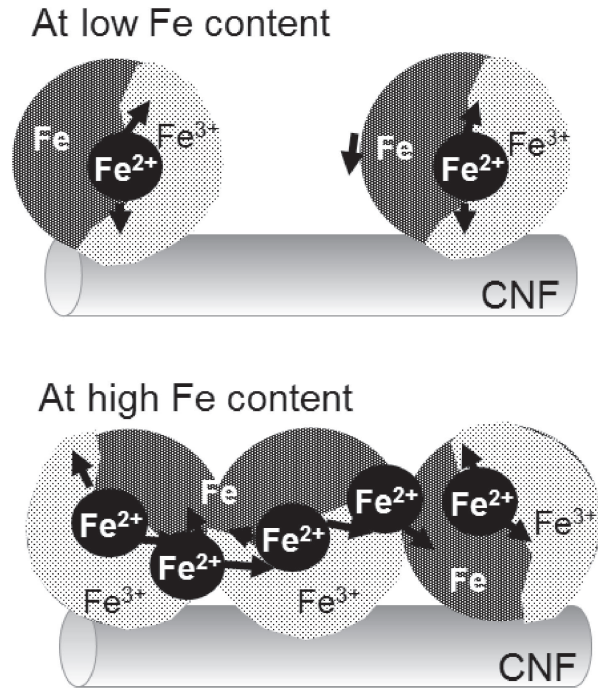

Figure 6. Schematic of the proposed model to explain connections among iron species particles.

moderate, with only $-0.8 \mathrm{~V}$ plateau, probably because of the imperfect connection between FeOOH and CNF. The lack of $-0.9 \mathrm{~V}$ plateau is rather reasonable from the assumption that the formation of intermediate species such as $\mathrm{FeOOH}$ at the plateau. The $\mathrm{Fe}(\mathrm{OH})_{x}(\mathrm{p}) /$ CNF containing $0.30 \mathrm{Fe}$ exhibits rather low capacity of iron. This composite was selected and molded into a pellet with $3 \mathrm{wt} \%$ of $\mathrm{FeOOH}$. The discharge profiles of $\mathrm{Fe}(\mathrm{OH})_{x}(\mathrm{p}) / \mathrm{CNF}$ with and without $\mathrm{FeOOH}$ are displayed in Fig. 4(b). The horizontal axis is the capacity value normalized by the iron mass, including the contribution from $\mathrm{FeOOH}$. The $\mathrm{FeOOH}$-added $\mathrm{Fe}(\mathrm{OH})_{x}(\mathrm{p}) / \mathrm{CNF}$ electrode exhibits considerably higher capacity, ca. $340 \mathrm{mAh}$ $(\mathrm{g} \mathrm{Fe})^{-1}$, than the same active material without $\mathrm{FeOOH}$. The SEM images of $\mathrm{Fe}(\mathrm{OH})_{x}(\mathrm{p}) / \mathrm{CNF}(\mathrm{Fe} 0.22), \mathrm{FeOOH}$, and $\mathrm{Fe}(\mathrm{OH})_{x}(\mathrm{p}) / \mathrm{CNF}$ with $3 \mathrm{wt} \% \mathrm{FeOOH}$ are presented in Fig. 5. FeOOH has needle-like particles with markedly larger sizes than $\mathrm{Fe}(\mathrm{OH})_{x}(\mathrm{p}) / \mathrm{CNF}$ (not observed clearly in the SEM micrographs, but the dimension is significant by the TEM image in Fig. 1(b)). $\mathrm{Fe}(\mathrm{OH})_{x}(\mathrm{p}) / \mathrm{CNF}$ shows that the SEM image with $\mathrm{FeOOH}$ particles appears to be dispersed without a change in their dimension. Therefore, the result of the constant-current clearly indicates the improvement of iron utilization by $\mathrm{FeOOH}$ in the composite electrode. Alternative results from the author indicate similar improvement of iron utilization by the coexistence of $\mathrm{Fe}^{2+}$ in the sol-gel prepared $\mathrm{Fe}(\mathrm{OH})_{x} / \mathrm{CNF}$ composites. ${ }^{23}$ A schematic model to explain the effect of connection between iron species on the composite via enhancement of the propagation of intermediate $\mathrm{Fe}^{2+}$ species is proposed as shown in Fig. 6. According to this model and the assumption of the acceleration of the redox by intermediate $\mathrm{Fe}^{2+}$, the $\mathrm{Fe}^{2+}$ density might be higher in the composite with a larger amount of iron species. Therefore, the utilization of iron might increase. In the case of the $\mathrm{FeOOH}$-added $\mathrm{Fe}(\mathrm{OH})_{x}(\mathrm{p}) / \mathrm{CNF}$ electrode, $\mathrm{FeOOH}$ is regarded as contributing to the acceleration of redox process of $\mathrm{Fe}(\mathrm{OH})_{x}$. Although it is difficult to obtain direct evidence to elucidate how such intermediates act, the optimum alignment of iron species for facile catalytic effect of intermediate species might be the reason for the recent remarkable development of iron utilization. ${ }^{14,15}$

\section{Conclusion}

The utilization of iron in composites of nano-sized iron species and carbon nanofibers with varying preparation procedures and iron contents has been compared. Not only nominal capacities but the capacities per unit mass of iron increase by iron content in the iron species/carbon nanofiber composites irrespective of the composite preparation procedures. Composites with high utilization of iron have such textures as nano-sized particles of iron species that are mutually connected along CNF. It is considered that the connection between iron species facilitates the propagation of intermediate species such as $\mathrm{FeOOH}$. The highest values of the capacity per iron mass achieved in this study are 400-430 $\mathrm{mAh}(\mathrm{g} \mathrm{Fe})^{-1}$.

\section{Acknowledgments}

This work was supported by JSPS Kakenhi grant No. 25410250. The $\mathrm{VGCF}^{\mathrm{TM}}-\mathrm{X}$ sample was kindly provided by Showa Denko K.K., Japan.

\section{References}

1. B. Scrosati, Modern Batteries (eds. by C. A. Vincent, B. Scrosati), Wiley, New York, p. 292 (1997).

2. L. Öjefors and L. Carlson, J. Power Sources, 2, 287 (1978).

3. K. F. Blurton and A. F. Sammells, J. Power Sources, 4, 263 (1979).

4. K. Vijayamohanan, T. S. Balasubramanian, and A. K. Shukla, J. Power Sources, 34, 269 (1991).

5. H. G. Silver and E. Leaks, J. Electrochem. Soc., 117, 5 (1970).

6. B. Anderson and L. Öjefors, J. Electrochem. Soc., 123, 824 (1976).

7. D. MacDonald and B. Roberts, Electrochim. Acta, 23, 781 (1978).

8. S. Haupt and H.-H. Strehblow, Langmuir, 3, 873 (1987).

9. K. Micka and Z. Zábranský, J. Power Sources, 19, 315 (1987).

10. J. Černý, J. Jindra, and K. Micra, J. Power Sources, 45, 267 (1993).

11. K.-C. Huang and K.-S. Chou, Electrochem. Commun., 9, 1907 (2007).

12. C.-Y. Kao and K.-S. Chou, J. Power Sources, 195, 2399 (2010).

13. J. Urbaniak, J. M. Skowroński, and B. Oleinik, J. Solid State Electrochem., 14, 1629 (2010).

14. C.-Y. Kao, Y.-R. Tsai, and K.-S. Chou, J. Power Sources, 196, 5746 (2011).

15. B. T. Hang, M. Egashira, I. Watanabe, S. Okada, J. Yamaki, S. Yoon, and I. Mochida, J. Power Sources, 143, 256 (2005). 
16. B. T. Hang, T. Watanabe, M. Egashira, I. Watanabe, S. Okada, and J. Yamaki, J. Power Sources, 155, 461 (2006).

17. B. T. Hang, T. Watanabe, M. Egashira, I. Watanabe, S. Okada, and J. Yamaki, Electrochem. Solid-State Lett., 8, A476 (2005).

18. B. T. Hang, H. Hayashi, S. H. Yoon, S. Okada, and J. Yamaki, J. Power Sources, 178, 393 (2008).

19. M. Egashira, J. Kushizaki, N. Yoshimoto, and M. Morita, J. Power Sources, 183
399 (2008).

20. M. Egashira, S. Nakayama, N. Yoshimoto, and M. Morita, Electrochemistry, 82, 273 (2014).

21. P. Periasamy, B. Ramesh Babu, and S. Venkatakrishna Iyer, J. Power Sources, 58, 35 (1996)

22. U. Casellato, N. Comisso, and G. Mengoli, Electrochim. Acta, 51, 5669 (2006). 23. M. Egashira, Electrochemistry, 83, 354 (2015). 